\title{
Wymagania stawiane elementom pochłaniającym energię zderzenia w wagonach-cysternach
}

\begin{abstract}
$W$ artykule przedstawiono wymagania dotyczace elementów pochłaniajacych energie $w$ wagonach-cysternach wynikajace z aktualnych przepisów międzynarodowych. Analiza wykazuje wzrost znaczenia bezpieczeństwa pasywnego przed skutkami zderzeń dla wagonów towarowych, zwłaszcza cystern przewożacych ładunki niebezpieczne. Obowiqzujace wymagania sq kolejnym poważnym wyzwaniem dla producentów pojazdów szynowych, którzy musza zagwarantować nowe rozwiqzania konstrukcyjne pochłaniajace energię zderzenia, nie zwiększajac drastycznie ceny nowo produkowanego oraz modernizowanego taboru.

Praca naukowa finansowana ze środków budżetowych na naukę w latach $2005 \div 2007$ jako projekt badawczy pt. „, Teoretyczne i techniczne możliwości ksztaltowania stref zgniotu ustrojów nośnych pojazdów szynowych."
\end{abstract}

\section{Wstęp}

W projektowaniu i produkcji wagonów towarowych, ze względu na liczebność w poszczególnych typach oraz konieczność ich stosowania do ruchu międzynarodowego, uwzględniono daleko idącą standaryzację. Dlatego też szczególnie ten typ pojazdów wymaga od konstruktorów, technologów oraz użytkowników taboru szczegółowej znajomości przepisów międzynarodowych zawartych w kartach UIC, raportach ORE/ERRI i normach europejskich EN.

Rozwiązania konstrukcyjne wagonów towarowych muszą umożliwić realizację przedsięwzięć sformułowanych przez raport ERRI B12/Rp.17 [18]:

- skoncentrowanie produkcji części zamiennych w możliwie dużych seriach i poprzez uniknięcie dużej ilości oprzyrządowania oraz osiągnięcie obniżenia kosztów produkcji

- przygotowanie części wagonów do wymiany między sobą

- ekonomicznej organizacji napraw i konserwacji wagonów towarowych przez zmniejszenie ilości typów konstrukcyjnych i części zamiennych.

Aspekt ekonomiczny sformułowany w ww. raporcie ERRI jest wciąż aktualny przy wzrastających wymaganiach dotyczących bezpieczeństwa pojazdów szynowych. Pojęcie bezpieczeństwa pojazdu szynowego podczas jego eksploatacji zostało $\mathrm{w}$ ostatnich latach bardzo rozszerzone, zwłaszcza w zakresie zderzeń [1]. Nakłada to na producenta obowiązek zabezpieczenia konstrukcji przed skutkami zderzeń nadzwyczajnych, czyli przy przekroczeniu prędkości nabiegania wynoszącej $12 \mathrm{~km} / \mathrm{h}$ (uznanej jako normalną prędkość eksploatacyjna, która nie powinna spowodować uszkodzeń prawidłowo skonstruowanych wagonów).
Z praktyki eksploatacyjnej wynika jednak, że prędkość ta może być przekroczona nawet przy nabieganiach podczas rozrządu wagonów towarowych. Należy również brać pod uwagę skutki zderzeń z innymi pojazdami oraz przeszkodami, co w przypadku cystern przewożących ładunki niebezpieczne może mieć katastrofalne skutki dla środowiska naturalnego. Wynika stąd konieczność dodatkowych zabezpieczeń konstrukcyjnych przed skutkami zderzeń. Takimi elementami konstrukcyjnymi są przede wszystkim elementy zderzno-pochłaniające ( niem. crashelemente).

2.Wymagania dla elementów zderzno-pochłaniających montowanych w wagonach-cysternach

\subsection{Wymagania ogólne}

Obecnie eksploatowane wagony- cysterny, pod względem dopuszczalnego nacisku zestawu kołowego na tor oraz maksymalnej prędkości, można podzielić na dwie grupy:

- wagony z dopuszczalnym naciskiem zestawu kołowego na tor $20 \mathrm{t}$; wagony te powinny posiadać możliwość osiagnięcia maksymalnej prędkości $100 \mathrm{~km} / \mathrm{h}$ w stanie załadowanym

- wagony z dopuszczalnym naciskiem zestawu kołowego na tor $22,5 \mathrm{t}$; wagony te powinny posiadać możliwość osiagnnięcia maksymalnej prędkości $100 \mathrm{~km} / \mathrm{h}$ względnie $120 \mathrm{~km} / \mathrm{h}$, jeśli maksymalny nacisk zestawu kołowego na tor nie przekracza $20 \mathrm{t}$.

Czteroosiowe wagony-cysterny powinny być wyposażone w standardowe układy biegowe zgodne z przepisami karty UIC 432 [4]. Jak wynika z praktyki wagony-cysterny są eksploatowane najczęściej w dwóch 
stanach obciążenia: „próżny” oraz „ładowny” przy wykorzystaniu maksymalnej granicy ładowności. W tabeli 1 podano wybrane parametry konstrukcyjne nowoczesnych wagonów-cystern, eksploatowanych obecnie na sieci kolejowej DB AG i wyprodukowanych przez przemysł niemiecki w latach dziewięćdziesiątych XX wieku [16]. W tabeli 2 przedstawiono dopuszczalne ładowności tych wagonów-cystern dla różnych klas torów A, B, C i D wg karty UIC 700 $\lceil 15\rceil$.

\section{Wybrane parametry konstrukcyjne wagonów-cystern wg [16]}

\begin{tabular}{|c|c|c|c|c|c|c|c|}
\hline L.p & $\begin{array}{c}\text { Typ } \\
\text { wagonu }\end{array}$ & $\begin{array}{c}\text { Masa } \\
\text { własna } \\
{[\mathrm{kg}]}\end{array}$ & $\begin{array}{c}\text { Nacisk } \\
\text { zestawu } \\
\text { kołowego } \\
\text { na szyny } \\
{[\mathrm{t}]}\end{array}$ & $\begin{array}{c}\text { Baza } \\
\text { wagonu } \\
{[\mathrm{m}]}\end{array}$ & $\begin{array}{c}\text { Długość } \\
\text { wagonu ze } \\
\text { zderzakami } \\
{[\mathrm{m}]}\end{array}$ & $\begin{array}{c}\text { Pojemność } \\
\text { użytkowa } \\
\text { wagonu } \\
{\left[\mathrm{m}^{3}\right]}\end{array}$ & Uwagi \\
\cline { 1 - 7 } 1 & 1695.85 & 23800 & 22.5 & 11.560 & 16.600 & 95 & \\
\hline 2 & 8098.81 & 30200 & 22.5 & 15.600 & 20.840 & 128 & \multirow{2}{*}{$* *)$} \\
\hline 3 & 5270.83 & 25100 & 22.5 & 11.360 & 16.400 & 70 & \\
\hline 4 & 4737.80 & 24100 & 22.5 & 9.360 & 14.400 & 37 & \\
\hline 5 & 5356.81 & 23500 & 20 & 12.000 & 17.900 & 56 & \\
\hline 6 & $*)$ & 27000 & 22.5 & 11.060 & 12.300 & 63 & \\
\hline 7 & 7299.82 & 28300 & 22.5 & 12.750 & 18.690 & 113 & \\
\hline
\end{tabular}

*) wagon znany $w$ Niemczech jako ,, mobile Fernwärme”

**) wagony cysterny sq wyposażone $w$ standardowe uktady biegowe wymienione w karcie UIC 432 [4]

\section{Zestawienie ladowności wagonów-cystern w zależności} od prędkości wg [16]

Tabela 2

\begin{tabular}{|c|c|c|c|c|c|c|c|c|c|}
\hline \multirow[t]{4}{*}{ L.p. } & \multirow[t]{4}{*}{$\begin{array}{c}\text { Typ } \\
\text { wagonu }\end{array}$} & \multicolumn{4}{|c|}{$\begin{array}{l}\text { Ładowności dla poszczególnych } \\
\text { wagonów cystern dla rożnych klas } \\
\text { toru [t], prędkość } 90 \mathrm{~km} / \mathrm{h}\end{array}$} & \multicolumn{4}{|c|}{$\begin{array}{l}\text { Ladowności dla poszczególnych wa- } \\
\text { gonów cystern dla rożnych klas toru } \\
{[\mathrm{t}] \text {, prẹdkość } 100 \mathrm{~km} / \mathrm{h}}\end{array}$} \\
\hline & & $\mathrm{A}$ & B & $\mathrm{C}$ & $\mathrm{D}$ & $\mathrm{A}$ & B & $\mathrm{C}$ & $\mathrm{D}$ \\
\hline & & \multicolumn{4}{|c|}{$\begin{array}{l}\text { Dopuszczalny nacisk zestawu ko- } \\
\text { towego na szyny }[\mathrm{t}]\end{array}$} & \multicolumn{4}{|c|}{$\begin{array}{l}\text { Dopuszczalny nacisk zestawu kołowe- } \\
\text { go na szyny }[\mathrm{t}]\end{array}$} \\
\hline & & 16 & 18 & 20 & 22.5 & 16 & 18 & 20 & 22.5 \\
\hline 1 & 1695.85 & 40.2 & 48.2 & 56.2 & 66.2 & 40.2 & 48.2 & 56.2 & 56.2 \\
\hline 2 & 8098.81 & 33.8 & 41.8 & 49.8 & 59.8 & 33.8 & 41.8 & 49.8 & 49.8 \\
\hline 3 & 5270.83 & 38.9 & 46.9 & 54.9 & 64.9 & 38.9 & 46.9 & 54.9 & 54.9 \\
\hline 4 & 4737.80 & 39.9 & 47.9 & 55.9 & 65.9 & 39.9 & 47.9 & 55.9 & 55.9 \\
\hline 5 & 5356.81 & 40.5 & 48.5 & 56.5 & - & 40.5 & 48.5 & 56.5 & - \\
\hline 6 & *) & 37.0 & 45.0 & 53.0 & 63.0 & 37.0 & 45.0 & 53.0 & 63.0 \\
\hline 7 & 7299.82 & 35.7 & 43.7 & 51.7 & 61.7 & 35.7 & 43.7 & 51.7 & 61.7 \\
\hline
\end{tabular}

*) wagon znany w Niemczech jako „, mobile Fernwärme”

Wartości wskaźnika obciążenia użytkowego do objętości użytkowej dla różnych typów wagonów-cystern wg [16]

Tabela 3

\begin{tabular}{|c|c|c|c|c|c|c|c|}
\hline L.p. & $\begin{array}{c}\text { Typ } \\
\text { wagonu }\end{array}$ & $\begin{array}{c}\text { Pojem- } \\
\text { ność } \\
\text { użytkowa } \\
\text { wagonu } \\
{\left[\mathrm{m}^{3}\right]}\end{array}$ & $\begin{array}{c}\text { Maksy- } \\
\text { malna } \\
\text { ładowność } \\
\text { użytkowa } \\
{[\mathrm{t} \text { ] przy }} \\
90 \mathrm{~km} / \mathrm{h}\end{array}$ & $\begin{array}{l}\text { Wskaźnik: ob- } \\
\text { ciążenie uży- } \\
\text { teczne do objęto- } \\
\text { ści } \\
\text { użytkowej } \\
{\left[\frac{t}{m^{3}}\right]}\end{array}$ & $\begin{array}{c}\text { Maksymalna } \\
\text { ladowność } \\
\text { użytkowa } \\
{[\mathrm{t}] \mathrm{przy}} \\
100 \mathrm{~km} / \mathrm{h}\end{array}$ & $\begin{array}{c}\text { Wskaźnik: } \\
\text { obciążenie } \\
\text { użyteczne } \\
\text { do objętości } \\
\text { użytkowej } \\
{\left[\frac{t}{m^{3}}\right]}\end{array}$ & Uwagi \\
\hline 1 & 1695.85 & 95 & 66.2 & 0.69 & 56.2 & 0.59 & \\
\hline 2 & 8098.81 & 128 & 59.8 & 0.46 & 49.8 & 0.38 & \\
\hline 3 & 5270.83 & 70 & 64.9 & 0.92 & 54.9 & 0.78 & \\
\hline 4 & 4737.80 & 37 & 65.9 & 1.78 & 55.9 & 1.51 & $* *)$ \\
\hline 5 & 5356.81 & 56 & 56.5 & 1.00 & 56.5 & 1.00 & \\
\hline 6 & *) & 63 & 63 & 1.00 & 63 & 1.00 & \\
\hline 7 & 7299.82 & 113 & 61.7 & 0.54 & 61.7 & 0.54 & \\
\hline
\end{tabular}

*) wagon znany w Niemczech jako „,mobile Fernwärme”

**) wagon uznany jako optymalna konstrukcja w zakresie wagonów-cystern z uwagi na osiagnięty wskaźnik obciqżenia użytecznego do objętości użytkowej
Konstruktorzy cystern powinni brać pod uwage przy każdych zmianach, dotyczących budowy nowoczesnych cystern, dotychczas obowiązujące przepisy zawarte $\mathrm{w}$ następujących kartach UIC i raportach ERRI:

- karcie UIC 505-1 [5] dotyczącej skrajni kinematycznej

- karcie UIC 521 [8] dotyczącej swobodnej przestrzeni, którą należy utrzymać na końcach wagonów towarowych

- karcie UIC 530-2 [10] dotyczącej bezpieczeństwa jazdy podczas przejazdu przez łuk ,S”

- karcie UIC 533 [11] dotyczącej zabezpieczenia przez uziemienie wagonów przed porażeniem prądem elektrycznym personelu obsługującego

- karcie UIC 535-2 [12] dotyczącej wsporników sygnałowych

- karcie UIC 577 [14] dotyczącej ogólnych wymagań

wytrzymałościowych wynikających $\mathrm{z}$ obciążeń dla wagonów-cystern.

W szczególności należy przestrzegać następujących zasad: 
- Przy przeprowadzaniu prób nabiegania zgodnie $\mathrm{z}$ raportem ERRI B12/Rp.17 [18] nie może powstać żadne odkształcenie trwałe ( plastyczne) elementów zderzno- pochłaniających na wagonie-cysternie przy wystapieniu maksymalnego obciążenia; próby muszą być przeprowadzone przy prędkości max. $12 \mathrm{~km} / \mathrm{h}$

- Elementy zderzno-pochłaniające zintegrowane ze zderzakami lub zabudowane pomiędzy zderzakami i czołownicą muszą spełniać zachowanie przestrzeni zgodnie $\mathrm{z}$ kartą UIC 526-1, załącznik 2 [9]

- Elementy zderzno-pochłaniające muszą spełniać przepisy załącznika F karty UIC 573 [13]

- Wagony musza posiadać oznakowanie zgodne z przepisami RIV [19]

- Wagony-cysterny, które przewożą ładunki niebezpieczne muszą odpowiadać przepisom RID [17]

- W przypadku normalnej eksploatacji, w której występują nabiegania do prędkości 12 $\mathrm{km} / \mathrm{h}$, w elementach zderzno-pochłaniających nie mogą powstać żadne odkształcenia trwałe.

W przypadku wagonów towarowych pasywne bezpieczeństwo zyskuje coraz bardziej na znaczeniu, przy czym obok ochrony ładunków oraz personelu obsługującego, bardzo ważny aspekt oceny taboru do przewozów towarowych stanowi obniżenie kosztów utrzymania i konserwacji, napraw oraz zwiększająca się dyspozycyjność wagonu do eksploatacji.

Punktem wyjścia do określenia wymagań szczegółowych dla elementów zderzno-pochłaniających jest precyzyjne określenie stanów eksploatacyjnych, jakim powinny one sprostać i tak:

- 1-szy stopień (zakres) eksploatacji obejmuje normalną eksploatację przetokowo-manewrową i lekkie zderzenia, które sprowadzają się do nabiegań wagonu do prędkości 12 $\mathrm{km} / \mathrm{h}$; górna granica tego stopnia eksploatacji musi mieć zakres do prędkości $15 \mathrm{~km} / \mathrm{h}$

- 2-gi stopień ( zakres ) eksploatacji obejmuje ciężkie kolizje z prędkościami do $40 \mathrm{~km} / \mathrm{h}$. W tym przypadku cała energia zderzenia powinna być przejęta przez elementy zderznopochłaniające. Konstrukcja pojazdu i pozostałe urządzenia zewnętrzne powinny pozostać nieuszkodzone. $Z$ reguły naprawa wagonu po kolizjach z taką prędkością sprowadza się do wymiany elementów zderzno-pochłaniających na nowe. Zdarzają się przypadki naprawy korpusu zderzaka, aby z powrotem przygotować do eksploatacji zderzak z elementami zderznopochłaniającymi.
- 3-ci stopień (zakres) eksploatacji obejmuje bardzo ciężkie kolizje z prędkościami powyżej $40 \mathrm{~km} / \mathrm{h}$. Należy liczyć się z uszkodzeniami w pojazdach uczestniczących w zderzeniach, ale można jednocześnie ograniczyć ich rozmiary, bez specjalnego badania pojazdów uczestniczących w wypad-ku. Zapewniając dużą aktywną wartość trwałego odkształcenia wzdłużnego można osiagnąc również skuteczną ochronę przed „wspinaniem” się pojazdu w trakcie zderzenia.

Przy małych odkształceniach trwałych elementów zderzno-pochłaniających może się okazać, że dalsza eksploatacja jest możliwa do następnej naprawy okresowej. Dopóki nie jest „wyczerpane” odkształcenie elementów zderzno-pochłaniających można założyć, że istnieje pewność co do tego, iż w żadnej chwili zderzenia wielkość opóźnienia nie przekroczy wartości dopuszczalnej określonej podczas projektowania. Uzasadnieniem wprowadzenia dodatkowych środków zabezpieczających przed skutkami zderzeń jest struktura wypadków, które miały miejsce w latach $1985 \div 1995$ na sieci DB AG wg [3] ( tabela 4). Szczególnego znaczenia nabiera fakt, że najwięcej wypadków w analizowanym okresie wydarzyło się przy prędkości do $36 \mathrm{~km} / \mathrm{h}$.

\subsection{Wymagania szczegółowe}

Koncepcja elementów zderzno-pochłaniających opiera się na zasadniczym założeniu, że w przypadku tradycyjnego wyposażenia w zderzaki, dopuszczalna wielkość przemieszczenia wynikającego ze zderzeń pojawiających się w normalnej eksploatacji wynosi $105 \mathrm{~mm}$ ( skok zderzaka). Wobec faktu, że długość zderzaka w stanie swobodnym wynosi $620 \mathrm{~mm}$, to rezerwa konstrukcyjna, która może być wykorzystana przy zderzeniach nadzwyczajnych wynosi $505 \mathrm{~mm}$. W świetle aktualnych wymagań dotyczących pasywnego bezpieczeństwa pojazdów szynowych ta rezerwa może być uznana jako wada dzisiejszych konwencjonalnych rozwiązań. Dla pojazdów z wysokimi prędkościami zgodnie z Dyrektywą Europejską wg [2] zaleca się, aby były one przystosowane dla przejęcia energii zderzenia wynoszącej $1000 \mathrm{~kJ}$ na jeden koniec pojazdu przy wielkości odkształcenia trwałego wynoszącego $270 \mathrm{~mm}$. W przypadku wagonów towarowych i lokomotyw zrealizowanie takiego wymagania nie wydaje się możliwe z uwagi na bardzo ograniczoną przestrzeń do możliwej zabudowy elementów zderzno-pochłaniających.

Elementy pochłaniające energię przy zderzeniach nadzwyczajnych powinny zaabsorbować energię odpowiadającą prędkości nabiegania wynoszącej

$18 \div 54 \mathrm{~km} / \mathrm{h}(5 \div 15 \mathrm{~m} / \mathrm{s})$.

Odbiory elementów pochłaniających energię, zabudowanych w zderzakach lub pomiędzy zderzakami lub czołownicą pojazdu muszą być przeprowadzone $\mathrm{z}$ uwzględnieniem następujących wymagań: 
Zestawienie wypadków na sieci kolejowej DB AG w latach 1985:1995 wraz ze strukturą ich skutków wg [3]

Tabela 4

\begin{tabular}{|c|c|c|c|c|c|}
\hline $\begin{array}{c}\text { Zestawienie wypadków kolejowych } \\
\text { z wagonami-cysternami w latach } \\
1985 \div 1995\end{array}$ & \multicolumn{2}{|c|}{ Wyciek ładunku niebezpiecznego } & \multicolumn{2}{c|}{$\begin{array}{c}\text { Uszkodzenia na cysternach z } \\
\text { wyciekiem ładunku podczas } \\
\text { wypadku }\end{array}$} \\
\hline zderzenie czołowe & $45,7 \%$ & zderzenie czołowe & $26,3 \%$ & $\begin{array}{c}\text { armatura, urządzenia } \\
\text { opróżniajace, }\end{array}$ & $34 \%$ \\
\hline zderzenie boczne & $9,4 \%$ & zderzenie boczne & $6,9 \%$ & płaszcz zbiornika & $23 \%$ \\
\hline wykolejenie & $43,5 \%{ }^{1)}$ & wykolejenie & $5,7 \%$ & dno zbiornika & $39 \%$ \\
\hline pozostałe wypadki & $1,4 \%$ & Pozostałe wypadki & $0,8 \%$ & osadzenie na siodle & $4 \%$ \\
\hline
\end{tabular}

${ }^{1)}$ z czego $35.9 \%$ stanowiq wykolejenia zwiqzane z przewróceniem pojazdu

- wkład elementów sprężystych musi spełniać wymagania karty UIC 526-1 [9]

- próbę statyczną należy przeprowadzić dla uzyskania pełnego odkształcenia sprężystego lub plastycznego przy prędkości próbnej wynoszącej maksymalnie $5 \mathrm{~mm} / \mathrm{s}$. Siły: inicjująca i średnia siła wywołująca odkształcenia w zakresie plastycznym są mierzone

- próbę dynamiczną należy przeprowadzić ( próba stanowiskowa lub rzeczywista) na pojeździe $\mathrm{z}$ elementem pochłaniającym energię, przy prędkości nabiegania 5 do $15 \mathrm{~m} / \mathrm{s}$. Masę i energię należy dobrać tak, aby osiagnąć przynajmniej $\mathbf{7 5 \%}$ nominalnego odkształcenia w zakresie plastycznym, przy czym siła inicjująca musi być większa niż 1500 kN. Średnia siła odkształcenia zakresu plastycznego musi być mniejsza niż 2200 kN

- bilansu energetycznego dokonuje się na podstawie dwóch następujących po sobie prób zgodnie ze wzorem:

$$
W_{d}=W_{S}+\bar{F}_{d} \cdot S_{P}
$$

gdzie:

$$
\begin{aligned}
& \mathrm{W}_{\mathrm{d}-} \text { energia przejęta } \\
& \mathrm{W}_{\mathrm{s}} \text {-energia przejęta } \mathrm{w} \text { zakresie sprę- } \\
& \text { żystym } \\
& \bar{F}_{d} \text {-średnia , dynamiczna siła od- } \\
& \text { kształcenia w zakresie plastycz- } \\
& \text { nym } \\
& \text { Sp-nominalne odkształcenie w za- } \\
& \text { kresie plastycznym, które zosta- } \\
& \text { ło osiagnięte } \mathrm{W} \text { próbie statycz- } \\
& \text { nej. }
\end{aligned}
$$

Energia $\mathrm{W}_{\mathrm{d}}$ musi być większa lub równa $\mathbf{4 0 0} \mathbf{~ k J}$ dla elementów pochłaniających energię dla nowobudowanych wagonów towarowych, a dla elementów pochłaniających energię dla istniejących wagonów, które były budowane przed 1-szym stycznia 2005, większa lub równa $250 \mathrm{~kJ}$.
W przypadku elementów pochłaniających energię, które są zintegrowane (połączone) z konstrukcją pudła wagonu zagadnienie dotyczące wymagań jest jeszcze otwarte.

Elementy pochłaniające (crashelemente) energię przy zderzeniach nadzwyczajnych moga posiadać alternatywną zabudowę tzn. albo są zintegrowane ze zderzakami ( zabudowane w zderzakach ) lub są zabudowane pomiędzy zderzakami i ostoją wagonu.

Z dotychczasowych doświadczeń wynika, że są to plastycznie odkształcalne elementy posiadające kształt rurowy, wykonane $\mathrm{z}$ metalu lub elementy posiadające konstrukcję węzową (plastra pszczelego). Elementy pochłaniające energię podczas eksploatacji nadzwyczajnej są stosowane zarówno w pojazdach szynowych do transportu osobowego jak również do transportu towarowego. We wszystkich przypadkach elementów zderzno-pochłaniających obowiązuje zasada utrzymania ich minimalnej masy własnej, co jest zgodne $\mathrm{z}$ nowoczesnymi tendencjami rozwojowymi wagonów towarowych, gwarantując przy ograniczeniu dopuszczalnego nacisku zestawu kołowego na tor dla poszczególnych klas toru maksymalną ładowność. Jest to jeden $\mathrm{z}$ istotnych parametrów użytkowo-eksploatacyjnych oceny elementu zderzno-pochłaniającego oraz wagonu-cysterny jako całości.

Elementy zderzno-pochłaniające powinny być przystosowane do przejmowania energii w najbardziej niekorzystnych sytuacjach eksploatacyjnych tzn.:

- przy ekscentrycznym obciążeniu wynikającym ze współpracy dwóch sąsiednich wagonów w kierunku pionowym oraz poziomym; ekscentryczność w kierunku pionowym może wynikać z sprzężenia dwóch wagonów-cystern: jednego $\mathrm{w}$ stanie nowym oraz drugiego $\mathrm{w}$ stanie zużytym ( ekscentryczność w kierunku pionowym wynosi ok. $40 \mathrm{~mm}$ ). Ekscentryczność w tym kierunku może osiagać jeszcze większe wartości np. wynikające z maksymalnej i minimalnej wysokości zderzaków określonych w przepisach RIV [19]. Ekscentryczność w kierunku poziomym może wynikać z 
luzów poprzecznych przymaźniczych oraz ze współpracy wagonu wyposażonego w skrajnie zużyte zestawy kołowe $\mathrm{z}$ wagonem $\mathrm{w}$ stanie nowym

- przy skośnym zderzeniu, które może wystąpić na łuku o najmniejszym promieniu; dla $\mathrm{R}=150$ $\mathrm{m}$ kąt skośnego zderzenia przyjmuje się jako $10^{\circ}$.

2.2.1. Bezpieczeństwo pasywne wagonów-cystern budowanych przed styczniem 2005 roku $z$ elementami pochlaniającymi zabudowanymi w zderzakach

W przypadku wagonów wyprodukowanych przed styczniem 2005 z elementami pochłaniającymi zabudowanymi w zderzakach (zintegrowanych ze zderzakami) elementy sprężyste powinny posiadać możliwość przejęcia łącznej energii przez odkształcenia sprężyste oraz plastyczne $\geq \mathbf{5 0 0} \mathbf{~ k J}(0,5 \mathrm{MJ})$, natomiast w przypadku energii mniejszej niż $250 \mathrm{~kJ}$ nie powinno wystapić żadne odkształcenie trwałe.

Zgodnie z wytycznymi karty UIC 573 [13] każdy koniec wagonu wyposażonego $\mathrm{w}$ takie elementy powinien spełniać następujące wymagania:

- dynamiczna energia, która może być pochłonięta przez odkształcenie sprężyste zderzaka i plastyczne odkształcenie elementu pochłaniającego energię musi być $\geq \mathbf{2 5 0} \mathbf{~ k J}$

- dynamiczna siła, przy której następuje inicjacja odkształcenia plastycznego elementu pochłaniającego energię na prostym torze musi być $>1500$ kN

- średnia siła plastycznego odkształcenia elementu pochłaniającego energię musi być $<$ $2200 \mathbf{k N}^{1)}$

- urządzenie rejestrujące plastyczne odkształcenie, które jest zabudowane w zderzaku, musi spełniać następujące warunki:

- być widoczne w całym zakresie żywot ności zderzaka

- działać przy wystąpieniu odkształcenia plastycznego mniejszego niż 10 $\mathrm{mm}$

- zderzak wyposażony w dodatkowe elementy pochłaniające energię musi dodatkowo otrzymać w oznaczeniu literę $\mathbf{X}$ ( przykładowe oznaczenie $\mathbf{A X}$ lub $\mathbf{C X}$ ).

Wkład sprężysty zderzaka musi odpowiadać karcie UIC 526-1 [9]. Aby można było zastosować zderzaki kategorii A, nie może zadziałać element pochłaniająco-zderzny przy nabieganiach $\mathrm{z}$ prędkością do 12 $\mathrm{km} / \mathrm{h}$ przy zachowaniu warunków zgodnych $\mathrm{z}$ raportem ERRI B12Rp.17 [18] i nie może wystapić żadne przekroczenie dopuszczalnych naprężeń $\mathrm{w}$ materiale na wagonie ( czołownica, elementy połączeniowe, mocowanie zbiornika, zbiornik). Jeśli przynajmniej jeden z powyższych warunków nie zostanie zachowany, wówczas należy zastosować zderzaki kategorii C.

W przypadku wagonów budowanych przed styczniem 2005 roku z elementami pochłaniającymi energię zabudowanymi w konstrukcji wagonu sprawa sformułowania odpowiednich przepisów lub wymagań jest jeszcze otwarta.

\subsubsection{Bezpieczeństwo pasywne wagonów cystern nowobudowanych po styczniu 2005 roku $z$ elementami pochlaniającymi zabudowany- mi w zderzakach}

Dla wagonów-cystern zastosowanie tego typu elementów określa karta UIC 573 [13]. Zgodnie z wytycznymi tej karty UIC każdy koniec wagonu wyposażonego w takie elementy powinien spełniać następujące wymagania:

- elementy pochłaniające powinny posiadać możliwość przejęcia łącznej energii przez odkształcenia sprężyste oraz plastyczne $\geq \mathbf{8 0 0} \mathbf{~ k J}$ $(\mathbf{0 , 8}$ MJ), natomiast w przypadku energii mniejszej niż $400 \mathbf{~ k J}$ nie powinno wystapić żadne odkształcenie trwałe, co odpowiadałoby normalnej próbie nabiegania wagonu-cysterny w stanie ładownym o masie brutto $90000 \mathrm{~kg} \mathrm{z}$ prędkością $\mathrm{v}=12 \mathrm{~km} / \mathrm{h}$

- dynamiczna energia, która może być pochłonięta przez odkształcenie sprężyste zderzaka i plastyczne odkształcenie elementu pochłaniającego energię musi być $\geq \mathbf{4 0 0} \mathbf{~ k J}$

- dynamiczna siła, przy której następuje inicjacja odkształcenia plastycznego elementu pochłaniającego energię na prostym torze musi być $>1500 \mathrm{kN}$

- średnia siła plastycznego odkształcenia elementu pochłaniającego energię musi być $<2200$ kN $^{1)}$

- urządzenie wskazujące (rejestrujące) plastyczne odkształcenie, które jest zabudowane w zderzaku musi spełniać następujące warunki:

- być widoczne w całym zakresie żywotności zderzaka

- działać przy wystapieniu odkształcenia plastycznego mniejszego niż $10 \mathrm{~mm}$

- zderzak wyposażony w elementy pochłaniające energię musi dodatkowo otrzymać w oznaczeniu literę $\mathbf{X}$ ( przykładowe oznaczenie $\mathbf{A X}$ lub CX).

\footnotetext{
1) Podwozie wagonu musi być zbadane przy uwzględnieniu krótkotrwatej średniej siły plastycznego odkształcenia. Statyczna próba ściskania zgodnie z raportem ERRI B12/Rp 17 wystarczy do weryfikacji tego wymagania
} 
Wkład sprężysty zderzaka musi odpowiadać karcie UIC 526-1 [9]. Aby można było zastosować zderzaki kategorii A, nie może zadziałać element pochłaniająco-zderzny przy nabieganiach z prędkością $12 \mathrm{~km} / \mathrm{h}$ przy zachowaniu warunków zgodnych $\mathrm{z}$ raportem ERRI B12Rp.17 [18] i nie może wystapić żadne przekroczenie dopuszczalnych naprężeń $\mathrm{w}$ materiale na wagonie ( czołownica, elementy połączeniowe, mocowanie zbiornika, zbiornik).

Producenci elementów zderzno-pochłaniających muszą to udowodnić podczas prób nabiegania $\mathrm{w}$ stanie ładownym. Jeśli przynajmniej jeden $\mathrm{z}$ powyższych warunków nie zostanie zachowany, wówczas należy zastosować zderzaki kategorii C.

W przypadku wagonów budowanych po styczniu 2005 roku z elementami pochłaniającymi energię zabudowanymi w konstrukcji wagonu sprawa sformułowania odpowiednich przepisów lub wymagań jest jeszcze otwarta.

\subsection{Analizy teoretyczne}

Przy analizach teoretycznych zjawisk zderzeń z udziałem wagonów-cystern należy uwzględnić przede wszystkim specyfikę pojazdu. Wynika ona z przeznaczenia pojazdu, który w wielu przypadkach służy do przewozu ładunków niebezpiecznych, w związku z czym sprawy ochrony środowiska i ochrony personelu obsługującego mają znaczenie priorytetowe. Przy koncepcji nowych elementów zderzno-pochłaniających należy wziąć pod uwagę, że ustrój nośny cysterny (ostoja, zbiornik, połączenia) musi też być odporny na zderzenia. W związku z czym przy projektowaniu wagonów cystern należy zwrócić uwagę na gatunki stali o wysokiej granicy plastyczności. Wówczas zdolność do przejmowania jednostkowej energii $\left(\mathrm{kJ} / \mathrm{m}^{2}\right) \mathrm{w}$ zakresie sprężystym zwiększa się zgodnie z zależnością:

$$
\Phi=\frac{1}{2} \cdot \frac{R_{0,2}^{2}}{E}
$$

gdzie:

$\Phi-\quad j e d n o s t k o w a$ energia dla określonego materiału gwarantująca zakres odkształcenia sprężystego oraz braku odkształceń trwałych $\mathrm{w}$ materiale wyrażona $\mathrm{w}$ [MPa]

$R_{0.2-}$ granica plastyczności określonego gatunku stali [MPa]

E- moduł Younga; dla stali $2.05 \times 10^{5}\lceil\mathrm{MPa}$.

Tak więc wyposażenie wagonu-cysterny w określone elementy o dużej zdolności pochłania energii może okazać się zabiegiem niewystarczającym, jeśli weźmie się pod uwagę konstrukcję nośną nieodporną na zderzenia. Dotyczy to zwłaszcza wagonów-cystern modernizowanych, zbudowanych przed 1.01.1995. W przypadku nowobudowanych cystern poszukiwanie stali o wysokiej granicy plastyczności $R_{0.2}$ oraz wysokiej granicy wytrzymałości na rozciaganie $R_{\mathrm{m}}$ na wszystkie elementy nośne wydaje się być koniecznością wobec zwiększonych wymagań odporności konstrukcji przed skutkami zderzeń. Wyższe parametry wytrzymałościowe można otrzymać przez zwiększenie zawartości węgla jak również przez zwiększoną zawartość pierwiastków stopowych i ich umiejętną kombinację, co jednak może wpłynąć niekorzystnie na cieplny równoważnik węgla, a tym samym spawalność stali. Pewną trudność w projektowaniu wagonów mających spełnić wymagania przeciwuderzeniowe stanowi wymagane dostosowanie konstrukcji do montażu sprzęgu samoczynnego, który ma w przyszłości zastąpić obecne urządzenie cięgłowo-zderzne, sprzęg śrubowy oraz obydwa zderzaki [16]. Pewnym wyjściem naprzeciw obecnym wymaganiom dla nowobudowanych wagonów towarowych jest zachowanie $300 \mathrm{~mm}$ odległości pomiędzy końcem ostoi, a końcem zbiornika. Jest to ewentualna rezerwa chroniąca płaszcz zbiornika przed zgniotem w przypadku zderzenia. Tendencje rozwojowe wagonów cystern idą naprzeciw wymogom bezpieczeństwa. Okazuje się, że bardziej jest prawdopodobne zwiększenie nacisku zestawu kołowego na tor jako konsekwencja zwiększonej ładowności, niż zwiększenie prędkości. Nie jest przecież żadnym problemem zwiększenie prędkości w stanie ładownym do $120 \mathrm{~km} / \mathrm{h}$ przy nacisku zestawu kołowego na szyny $20 \mathrm{t}$, a nawet do $160 \mathrm{~km} / \mathrm{h}$ przy nacisku zestawu kołowego na szyny wynoszącym 18 t. Układy biegowe są do takiego ruchu przygotowane jak np. standardowy wózek Y37.

Podstawowym parametrem przy analizie zjawiska zderzeń jest energia kinetyczna poruszającego się pojazdu, którą można określić ze wzoru (2) podanego w [1].

Wartości energii kinetycznej dla wagonów cystern wyposażonych w różne układy biegowe przedstawiono w tabeli 5 .

Jak wynika $\mathrm{z}$ tabeli 5 , zwiększenie prędkości wagonów-cystern do prędkości $120 \mathrm{~km} / \mathrm{h}$ ( przy nacisku zestawu kołowego na szyny $20 \mathrm{t}$ lub 22.5 t) lub do 160 $\mathrm{km} / \mathrm{h}$ ( przy nacisku zestawu kołowego na szyny $18 \mathrm{t}$ ) jest mało prawdopodobne ze względu na zwiększenie ryzyka związanego $\mathrm{z}$ niekontrolowanym zderzeniem. Znacznie bezpieczniejsze wydaje się zwiększenie ładowności, poprzez zwiększenie dopuszczalnego nacisku zestawu kołowego na szyny wynoszącego $25 \mathrm{t}$ (wariant III). Wskaźnik wzrostu zdolności transportowych w stosunku do wariantu podstawowego wynosi 1.25 , przy takim samym wskaźniku wzrostu energii kinetycznej. W przypadku wariantu IV ( prędkość 120 $\mathrm{km} / \mathrm{h}$ i maksymalny nacisk zestawu kołowego na szyny 20 t) wskaźnik wzrostu zdolności transportowych zwiększył się tylko do 1.2, natomiast wskaźnik wzrostu energii kinetycznej aż do 1.44. Zwiększanie prędkości, nawet przy już przebadanych układach biego- 


\begin{tabular}{|c|c|c|c|c|c|c|}
\hline Numer wariantu & $\mathrm{W}$ ariant I & $\begin{array}{l}\text { W ariant } \\
\text { II }\end{array}$ & $\begin{array}{l}\text { Wariant } \\
\text { III }\end{array}$ & $\begin{array}{l}\text { W ariant } \\
\text { IV }\end{array}$ & $\mathrm{W}$ ariant $\mathrm{V}$ & $\begin{array}{l}\text { W ariant } \\
\text { VI }\end{array}$ \\
\hline $\begin{array}{l}\text { Typ układu } \\
\text { biegowego }\end{array}$ & $\begin{array}{l}\text { Y } 25 \mathrm{Cs} \\
\mathrm{Y} 25 \mathrm{Cs} 2 \\
\mathrm{Y} 25 \mathrm{Rs}\end{array}$ & $\begin{array}{l}\text { Y25Lsd } \\
\text { Y 25Lsd } 1\end{array}$ & Y $25 X L(s) s$ & $\begin{array}{c}\text { Y25Css } \\
\text { Y 25Rss } \\
\text { Y } 25 \mathrm{Ls}(\mathrm{s}) \\
\text { Y } 25 \mathrm{Ls}(\mathrm{s}) 1\end{array}$ & Y 25Lss & Y 37 \\
\hline $\begin{array}{c}\text { Prędkość } \\
\text { w km/h }\end{array}$ & 100 & 100 & 100 & 120 & 120 & 160 \\
\hline $\begin{array}{c}\text { Maks. nacisk } \\
\text { zestaw u koło- } \\
\text { wego na szyny } \\
\text { w t }\end{array}$ & 20 & 22.5 & 25 & 20 & 22.5 & 18 \\
\hline $\begin{array}{l}\text { Maks. masa } \\
\text { brutto w kg }\end{array}$ & 80000 & 90000 & 100000 & 80000 & 90000 & 72000 \\
\hline $\begin{array}{c}\text { Prędkość } \times \\
\text { masa } \mathrm{w} \\
\mathrm{km} / \mathrm{h} \times \mathrm{kg}\end{array}$ & 8000000 & 9000000 & 10000000 & 9600000 & 10800000 & $\begin{array}{l}11520 \\
000\end{array}$ \\
\hline $\begin{array}{l}\text { W skaźnik wzro- } \\
\text { stu zdolności } \\
\text { transportowych }\end{array}$ & 1 & 1.12 & 1.25 & 1.2 & 1.35 & 1.44 \\
\hline $\begin{array}{c}\text { Energia kine- } \\
\text { tyczna } \mathrm{w} \mathrm{kJ}\end{array}$ & 30864.19 & 34722.22 & 38580.24 & 44444.44 & 50000 & 71111.11 \\
\hline $\begin{array}{c}\text { W skaźnik wzro- } \\
\text { stu energii } \\
\text { kinetycznej }\end{array}$ & - & 1.12 & 1.25 & 1.44 & 1.62 & 2.304 \\
\hline
\end{tabular}

1) wskaźnik wzrostu odnosi się do wariantu I jako podstawowego

wych i dostosowanych do produkcji seryjnej oraz do eksploatacji międzynarodowej ( zachowanie prawidłowych własności biegowych przy różnych pochyleniach profilu główki szyny tzn. 1:20 dla SNCF, 1:30 dla SJ oraz 1:40 dla DB i PKP) wydaje się być bardzo kosztownym zabiegiem. Zwłaszcza dotyczy to wariantu $\mathrm{V}$ oraz VI. W tym przypadku układy biegowe Y25Lss oraz Y37 posiadają hamulec tarczowy, który ma wiele zalet ( mniejsza emisja hałasu do środowiska np. wagon z wózkami Y37 wykazuje taką samą emisję hałasu przy prędkości $160 \mathrm{~km} / \mathrm{h}$ jak wagon z wózkami standardowymi z zawieszeniem Y25 przy prędkości $120 \mathrm{~km} / \mathrm{h}$ ) ale to powoduje, że ten sam wagon jest droższy, zwłaszcza na etapie wytwarzania. Koszty wytwarzania samych układów biegowych Y37 z tytułu wyposażenia $\mathrm{w}$ hamulec tarczowy są trzykrotnie wyższe aniżeli układów biegowych standardowych Y25 przystosowanych do prędkości $120 \mathrm{~km} / \mathrm{h}$ i wyposażonych w hamulec klockowy. Kolejną istotną wadą zastosowania wózka Y37 są zwiększone luzy poprzeczne aż do $60 \mathrm{~mm}$, co przy klasycznych wózkach posiadających luz poprzeczny przymaźniczny wynoszący zaledwie $10 \mathrm{~mm}$ może stanowić istotne ograniczenie zarysu zewnętrznego pojazdu $\mathrm{z}$ tytułu zwiększonych zwężeń skrajni od zarysu odniesienia wg karty UIC 505-1 [5].

\section{Zestawienie wartości energii kinetycznych dla dwóch wybranych typów cystern} w różnych stanach eksploatacyjnych

Tabela 6

\begin{tabular}{|c|c|c|c|c|c|c|c|c|}
\hline \multirow[t]{3}{*}{$\begin{array}{l}\text { Typ } \\
\text { wagonu }\end{array}$} & \multirow[t]{3}{*}{$\begin{array}{l}\text { Stan } \\
\text { wagonu }\end{array}$} & \multicolumn{7}{|c|}{$\begin{array}{l}\text { Wartości energii kinetycznej w kJ dla poszczególnych stanów } \\
\text { eksploatacyjnych oraz prędkości zderzenia }\end{array}$} \\
\hline & & \multicolumn{4}{|c|}{$\begin{array}{l}\text { Zakres zderzeń I } \\
\qquad[\mathrm{km} / \mathrm{h}]\end{array}$} & \multirow{2}{*}{$\begin{array}{c}\text { Zakres } \\
\text { zderzeń } \\
\text { II } \\
{[\mathrm{km} / \mathrm{h}]} \\
\mathrm{v}=40\end{array}$} & \multicolumn{2}{|c|}{$\begin{array}{l}\text { Zakres zderzeń III } \\
\qquad[\mathrm{km} / \mathrm{h}]\end{array}$} \\
\hline & & $\mathrm{v}=3$ & $\mathrm{v}=7$ & $\mathrm{~V}=12$ & $\mathrm{v}=15$ & & $\mathrm{v}=100$ & $\mathrm{~V}=120$ \\
\hline \multirow{2}{*}{$\begin{array}{l}\text { Wagon } \\
5356.81 \\
23500 \\
\mathrm{~kg} \\
56 \mathrm{~m}^{3}\end{array}$} & $\begin{array}{l}\text { Stan } \\
\text { próżny }\end{array}$ & 8.15 & 44.42 & 130.55 & 203.99 & 1450.61 & 9066.35 & 13055.5 \\
\hline & $\begin{array}{l}\text { Stan } \\
\text { ładowny }\end{array}$ & 27.77 & 151.23 & 444.44 & 694.44 & 4938.27 & 30864.19 & \\
\hline \multirow{2}{*}{$\begin{array}{l}\text { Wagon } \\
8098.81 \\
30200 \\
\mathrm{~kg} \\
128 \mathrm{~m}^{3}\end{array}$} & $\begin{array}{l}\text { Stan } \\
\text { próżny }\end{array}$ & 10.48 & 57.09 & 167.77 & 262.15 & 1864.19 & 11651.23 & 16777.7 \\
\hline & $\begin{array}{l}\text { Stan } \\
\text { ładowny }\end{array}$ & 31.25 & 170.13 & 500 & 781.25 & 5555.55 & 34722.22 & \\
\hline
\end{tabular}


Zastosowanie ograniczników przesuwu pomiędzy wózkiem i pudłem wagonu może zredukować ten luz $60 \mathrm{~mm}$ na łuku o promieniu $\mathrm{R}=250 \mathrm{~m}$ do $18 \mathrm{~mm}$, co w znaczący sposób poprawia sytuację w zakresie wymaganych zwężeń w stosunku do zarysu odniesienia.

W tabeli 6 przedstawiono energię kinetyczną dla dwóch cystern tzn. dla cysterny typu 5356.81 o masie własnej $23500 \mathrm{~kg}$ i pojemności użytkowej $56 \mathrm{~m}^{3}$ oraz dla cysterny typu 8098.81 o masie własnej $30200 \mathrm{~kg}$ i pojemności użytkowej $128 \mathrm{~m}^{3}, \mathrm{z}$ uwzględnieniem różnych prędkości zderzeń.

Prędkości wynoszące odpowiednio 3, 7, 12 i $15 \mathrm{~km} / \mathrm{h}$ należą do pierwszego zakresu zderzeń, objętego kontrolowaną eksploatacją i udokumentowanego próbami nabiegania zgodnymi z raportem ERRI B12/Rp.17 [18]. Prędkość $3 \mathrm{~km} / \mathrm{h}$ występuje przy pracy manewrowej przeprowadzanej z bardzo dużą ostrożnościa, prędkość $7 \mathrm{~km} / \mathrm{h} \mathrm{z}$ zachowaniem przeciętnych środków ostrożności, natomiast przypadek prędkości 12 i $15 \mathrm{~km} / \mathrm{h}$ występuje przy pracy rozrządowej podczas staczania cystern $z$ górek rozrządowych i wymaga zastosowania hamulców torowych znajdujących się u podnóża górki rozrządowej wyposażonych w szczęki, zmniejszające prędkość staczanej cysterny. Zakres prędkości pomiędzy $15 \mathrm{~km} / \mathrm{h}$ oraz $40 \mathrm{~km} / \mathrm{h}$ jest drugim zakresem, ale już nie zakwalifikowanym do normalnej eksploatacji i jest traktowany jako przypadek nadzwyczajny. Zderzenia $\mathrm{z}$ prędkością $\mathrm{v}>40 \mathrm{~km} / \mathrm{h}$ można uznać jako przypadek ciężkiej kolizji, w których elementy zderzno-pochłaniające mogą już wyczerpać swój zakres działania.

Wychodząc z założenia, że element zderznopochłaniający musi posiadać zdolność do przejmowania energii większej niż 400 kJ ( 800 kJ na każdy koniec wagonu) można wyznaczyć prędkości nabiegania odpowiadające wartości tej energii.

Prędkość zderzenia dla cysterny o masie brutto 80000 $\mathrm{kg}$, odpowiadającą pochłonięciu energii $800 \mathrm{~kJ}$ wynosi:

$$
v_{M I N}=\sqrt{\frac{2 E}{m}}=\sqrt{\frac{2 \cdot 800000}{80000}} \cdot 3,6=16,09 \mathrm{~km} / \mathrm{h}
$$

Prędkość zderzenia dla cysterny o masie brutto 90 $000 \mathrm{~kg}$, odpowiadającą pochłonięciu energii $800 \mathrm{~kJ}$ wynosi:

$$
v_{M I N}=\sqrt{\frac{2 E}{m}}=\sqrt{\frac{2 \cdot 800000}{90000}} \cdot 3,6=15,17 \mathrm{~km} / \mathrm{h}
$$

W przypadku wagonu cysterny „458R” o masie własnej $25700 \mathrm{~kg}$ prędkość zderzenia odpowiadającą pochłonięciu energii $800 \mathrm{~kJ}$ wynosi:

$$
v_{M I N}=\sqrt{\frac{2 E}{m}}=\sqrt{\frac{2 \cdot 800000}{25700}} \cdot 3,6=28,40 \mathrm{~km} / \mathrm{h}
$$

Wyniki obliczeń potwierdzają niektóre poglądy wyrażane w literaturze światowej, że dla obecnie projektowanych elementów zderzno-pochłaniających należy zwiększyć możliwość przejmowania energii $\geq 500 \mathrm{~kJ}$ [2]. Powyższe rozważania obejmują wagony-cysterny wyposażone w standardowe układy biegowe, przystosowane do nacisku zestawu kołowego na tor wynoszącego $22.5 \mathrm{t}$ i spełniające wymagania karty UIC 518 [6] w zakresie własności dynamicznych pojazdu. W przypadku wagonów-cystern o zwiększonym nacisku zestawu kołowego na tor do $25 \mathrm{t}$ i spełniających wymagania karty UIC 518-2 [7] w zakresie własności dynamicznych należy uwzględnić, że przy obliczaniu prędkości zderzenia przy założonej energii kinetycznej, masa wagonu w stanie próżnym będzie większa oraz masa brutto wynosi $100 \mathrm{t}$.

\section{Wnioski}

Z przeprowadzonej analizy jednoznacznie wynika, że wagony-cysterny powinny być wyposażone $\mathrm{w}$ dodatkowe elementy pochłaniające energię zderzenia. Wyposażenie tych wagonów w urządzenia zderznopochłaniające powinno być zrealizowane $\mathrm{z}$ uwzględnieniem wszystkich wymagań zawartych w karcie UIC 573 [13]. Koniecznością wydaje się zabezpieczenie cystern przed skutkami zderzeń w II zakresie eksploatacyjnym ( do $40 \mathrm{~km} / \mathrm{h}$ ). W takim przypadku zabezpieczenie chroniłoby konstrukcję wagonu przed skutkami zderzenia wynikającymi również z przekroczenia dopuszczalnej prędkości $12 \mathrm{~km} / \mathrm{h}$ podczas rozrządu z górki rozrządowej. Problem może wyniknąć z tego, że wagony-cysterny, podobnie jak inne wagony towarowe, nie mają zbyt dużo miejsca na zabudowę dodatkowych elementów pochłaniających. Zabudowa elementów zderzno-pochłaniających może więc być nieskuteczna, jeśli nie będą przedsięwzięte jednoczesne prace nad zastosowaniem stali o wysokich parametrach wytrzymałościowych, użytych na inne zespoły i podzespoły konstrukcji nośnej wagonu. Stale te powinny wykazywać się dobrą udarnością i spawalnością ( utrzymanie cieplnego równoważnika węgla). Wysoka udarność stali powinna być utrzymana $\mathrm{w}$ szerokim zakresie temperatur, między innymi $\mathrm{w}$ temperaturach ujemnych $\left(-25^{\circ} \mathrm{C}\right.$ dla warunków środkowoeuropejskich oraz $-40^{\circ} \mathrm{C}$ dla krajów skandynawskich).

Powyższe zalecenia obowiązują już, zwłaszcza przy budowie nowych wagonów towarowych.

Elementy zderzno-pochłaniające muszą również zachować swoje własności pochłaniania energii w niskich temperaturach, co wymaga ich zbadania w komorach klimatycznych oraz przeprowadzenia $2 \div 3$ letniej eksploatacji obserwowanej na różnych typach wagonów- cystern. Eksploatacja obserwowana musiałaby objąć również okres zimowy z trudniejszymi 
warunkami klimatycznymi. Dotyczyłoby to elementów zderzno-pochłaniających zabudowanych w konstrukcji wagonu jak również zintegrowanych $\mathrm{z}$ konstrukcją zderzaków.

W świetle powyższych rozważań zastosowanie samych tylko elementów zderzno-pochłaniających może okazać się niewystarczające, aby całkowicie ochronić konstrukcję wagonu-cysterny przed skutkami zderzeń. Odporność na zderzenia wagonu jest również funkcją jego utrzymania. W związku z tym jego sprawność techniczna pomiędzy naprawami powinna być na bardzo wysokim poziomie. Dotyczy to również nadzoru podczas eksploatacji nad sprawnością elementów zderzno-pochłaniających.

\section{Literatura}

[1] Nowicki J., Sobaś M.: Kryteria oceny zabezpieczenia pojazdów szynowych przed skutkami zderzeń. Pojazdy Szynowe Nr 3/2006.

[2] Schneider S., Staub J.: Kombiniertes Puffer- und Deformationselement für Schienenfahrzeuge. ZEV +DET Glasers Annalen Nr. 123. 09.1999.

[3] Alstom LHB GmbH: Präsentation eines Sicherheits-Chemiekesselwagens Cesa mit Crashversuchen. ZEV+DET Glasers Annalen Nr. 124 07.2000.

[4] Karta UIC 432: Wagony towarowe. Prędkości jazdy. Warunki techniczne, które należy spetnić. Wydanie 10-te z sierpnia 2005.

[5] Karta UIC 505-1: Pojazdy kolejowe. Skrajnie pojazdów. Wydanie 10-te z maja 2006.

[6] Karta UIC 518: Badania i homologacja pojazdów kolejowych z punktu widzenia właściwości dynamicznych, bezpieczeństwa jazdy, obciqżenia toru i parametrów biegowych. 3-cie wydanie z sierpnia 2005.

[7] Karta UIC 518-2: Uzupetnienie do karty UIC 518: Zastosowanie do wagonów towarowych przystosowanych do nacisku zestawu kołowego większego niż 22.5 t $i$ do 25 t. 1-sze wydanie $z$ 06.2004.

[8] Karta UIC 521: Wagony pasażerskie i wagony bagażowe, wagony towarowe, pojazdy trakcyjne. Wolne przestrzenie do zarezerwowania na końcach pojazdów. 1-sze wydanie $z$ dnia 1.01.1987 z errata $z$ dnia 01.07.1990.

[9] Karta UIC 526-1:Wagony towarowe. Zderzaki o skoku $105 \mathrm{~mm}$. 2-gie wydanie z 01.07.1998.

[10] Karta UIC 530-2: Wagony towarowe. Bezpieczeństwo jazdy. 5-te wydanie z grudnia 2005.

[11] Karta UIC 533: Uziemianie ochronne części metalowych pojazdu. 2-gie wydanie $z$ 01.01.1977 z 4-ta zmianq z 01.01.1996.

[12] Karta UIC 535-2:Normalizacja i rozmieszczenie stopni, pomostów końcowych, mostków przejściowych, uchwytów, haków do lin, urzadzeń uruchamiajacych pociagowy sprzeg samoczynny i kurków końcowych powietrza wagonów towarowych ze względu na zastosowanie sprzęu samoczynnego na kolejach członkowskich UIC $i$ OSŻD. 4-te wydanie z 02.2006.

[13] Karta UIC 573: Warunki techniczne dotyczace budowy wagonów- cystern. 6-te wydanie $z$ 04.2005 .

[14] Karta UIC 577: Wagony towarowe. Obciqżenia. 4-te wydanie z 12.2005.

[15] Karta UIC 700: Klasyfikacja linii kolejowych. Przynależne granice obciqżenia wagonów towarowych. 10-te wydanie z 11.2004.

[16] ORE DT 320 (B12.B36): Aktualny stan techniki wagonów towarowych i perspektywy na najblizsza przyszłość. ( Der aktuelle Zustand der Güterwagentechnik und die Aussichten für die nahe Zukunft). Utrecht, październik 1990.

[17] RID: Regulamin dla międzynarodowego przewozu kolejami towarów niebezpiecznych (Reglement concernant le transport International ferroviaire des marchandises Dangereuses). Aneks 1 do załacznika B konwencji (Umowy) o międzynarodowym przewozie towarów kolejami (CIM). Grupa PKP-Przewozy Towarowe CARGO. Wyd. 01.07.2001.

[18] Raport końcowy ERRI B12/ Rp.17 (8-me wydanie): Program prób wagonów towarowych $z$ podwoziem i struktura wagonu ze stali (które nadaja się do zabudowy sprzęgu samoczynngo pracujacego na rozciaganie $i$ na ściskanie) $i$ których wózki maja ramę stalowq. (Versuchsprogramm für Güterwagen mit Untergestell und Wagenstrukturen aus Stahl (die für den Einbau der Automatischen Zug-Druck Kupplung geeignet sind) und deren Drehgestelle mit stählernem Drehgestellrahmen.) Utrecht, kwiecien 1997.

[19] RIV: Umowa o wymianie i użytkowaniu wagonów towarowych przez kolejowe przedsiębiorstwa przewozowe ( Regolamento Internazionale Veicoli). Wydanie obowiazuiace od 07.2000. 